\title{
Acute phase proteins in cats
}

\author{
Rita Mourão Rosa ${ }^{1}$ (D) Lisa Alexandra Pereira Mestrinho ${ }^{*}$ \\ ${ }^{1}$ Hospital Escolar Veterinário, Faculdade de Medicina Veterinária da Universidade de Lisboa (ULisboa), Lisboa, Portugal \\ ${ }^{2}$ Centro interdisciplinar de investigação em sanidade animal (CIISA), Faculdade de Medicina Veterinária da Universidade de Lisboa (Ulisboa), \\ Avenida da Universidade Técnica, 1300-477, Lisboa, Portugal. E-mail: lmestrinho@fmv.ulisboa.pt. "Corresponding author.
}

ABSTRACT: Acute phase proteins (APP) are proteins synthesized and released largely by hepatocytes upon the occurrence of cell damage or invasion by microorganisms. This article reviews the use of APP in feline diseases, identifying their usefulness in the clinical setting, analyzing 55 published papers. Serum amyloid A, alpha-1 acid glycoprotein, and haptoglobin are the indicators pointed out by the authors as useful in monitoring the acute inflammatory response in cats. Although, APP measurement is still not routinely used in veterinary medicine, together with clinical signs and other blood parameters, was of clinical interest and applicability in diseases such as feline infectious peritonitis, pancreatitis, renal failure, retroviral and Calicivirus infections. Although, there are commercially available kits for dosing feline APP, assay standardization aiming technical simplicity, more species specificity and with less associated costs will allow routine use in feline practice, as it is done in the human field.

Key words: inflammation, acute phase proteins, cat.

Proteínas de fase aguda em gatos

RESUMO: As proteinas de fase aguda (PFA) são proteínas sintetizadas e libertadas em grande parte por hepatócitos ao mesmo tempo da ocorrência de lesão celular ou invasão por microrganismos. Este artigo revê a utilização das PFA nas doenças do gato identificando a sua potencial utilidade no contexto clínico, analisando 55 artigos publicados. A amiloide sérica A, a alfa-1 glicoproteina ácida e a haptoblobina são os marcadores apontados pelos autores como úteis na monitorização da resposta aguda inflamatória nesta espécie. Embora o doseamento das PFA ainda não seja rotineiramente utilizado na medicina veterinária, o seu doseamento, em conjunto com sinais clínicos e outros meios complementares de diagnóstico, revelou interesse e aplicabilidade clínica em doenças tais como a peritonite infeciosa felina, pancreatite, insuficiência renal, infeções retrovirais e por Calicivírus. Apesar de existirem kits comercialmente disponíveis para dosear as PFA felinas, será necessária uma padronização de ensaios no sentido da melhoria da sua simplicidade técnica, da sua especificidade para o gato e com menores custos associados, para que sejam utilizados de forma rotineira, tal como são utilizados em medicina humana.

Palavras-chave: inflamação, proteinas de fase aguda, gato.

\section{INTRODUCTION}

The acute phase response (APR) is an early, non-specific systemic innate immune reaction to local or systemic stimulus, which helps to heal and re-establish homeostasis and minimize tissue damage when the body is affected by trauma, infection, stress, surgery, neoplasia or inflammation (GRUYS et al., 2005; CRAY et al., 2009; ECKERSALL \& BELL, 2010). In this reaction we observe several different systemic effects: fever, leukocytosis, hormone shifts-mainly cortisol and thyroxine concentrations, with a secondary catabolic state and muscle protein depletion, serum depletion of iron and zinc, among others (CERÓN et al. 2005, JAVARD et al. 2017).
Under the influence of IL- $1 \beta$, TNF- $\alpha$, and especially IL-6, and about 90 minutes after injury, protein synthesis is increased on hepatocytes, lymph nodes, tonsils, and spleen as well as in blood leukocytes. Those newly produced proteins are called acute phase proteins (APP) (TIZARD, 2013b).

\section{Acute phase proteins}

The APP concentrations can increase (positive APP) or decrease (negative APP) (PALTRINIERI et al., 2008) in response to inflammation (JOHNSTON \& TOBIAS, 2018). They can activate leukocytosis and the complement, cause protease inhibition, lead to clotting and opsonisation -a defense mechanism that lead to the elimination of infectious agents, tissue repair 
and restoration of the healthy state (CRAY et al., 2009). The APP can have two functions, a proor/and an anti-inflammatory effect, which must be delicately balanced to promote homeostasis (HOCHEPIED et al., 2003).

Three major groups of APP are recognized, based on response magnitude and duration secondary to stimulus (MURATA et al., 2004; PETERSEN et al., 2004; CERÓN et al., 2005).Positive APP can be divided in two groups: the first group, which includes APP with increases of 10 to 1000 times in humans or 10 to 100 times in domestic animals in the presence of inflammation-e.g. C-reactive protein (CRP) and serum amyloid A (SAA); and a second group, which corresponds to APP that increase 2 to 10 times in inflammatory response-e.g. haptoglobin and alpha-globulins. The last group included negative APP, where concentration decreases in response to inflammation - e.g. albumin (KANN et al., 2012).

\section{Positive acute phase proteins}

Positive APP are glycoproteins in which serum concentrations increase by $25 \%$ upon stimulation by pro inflammatory cytokines during disease process, being released in the blood stream. These concentrations can be measured and used in the diagnosis, prognosis, to monitor treatment response, as well as for general health screening. They also can be considered quantitative biomarkers of disease, highly sensitive to inflammation but poorly specific, since elevation of APP can occur in non-inflammatory diseases as well (CERÓN et al., 2005; ECKERSALL \& BELL, 2010).

Positive APP respond differently to cytokines, being these groups divided into two major classes. Type 1 APP, which include AGP, complement component 3, SAA, CRP, haptoglobin and hemopexin, are regulated by IL-1, IL- 6 and TNF- $\alpha$ and also by glucocorticoids. Type 2 which includes the three fibrinogen chains $(\alpha-, \beta$-, and $\gamma$-fibrinogen) and various inhibitory proteases, are regulated by IL-6 and glucocorticoid cytokines (BAUMANN et al., 1990; BAUMANN \& GAULDIE, 1994).

In cats, SAA or alpha-1-acid glycoprotein (AGP) are the most relevant APP. Blood SAA levels can indicate inflammatory conditions such as feline infectious peritonitis (FIP) and other infectious diseases such as caliciviral infection, chlamydiosis, leukemia, and infectious immunodeficiency since it increases by 10 - to 50 -fold(TIZARD, 2013b). The SAA can also be elevated in other diseases like diabetes mellitus and cancer. Haptoglobin usually increases 2- to 10-fold and is especially high in FIP (TIZARD, 2013b). Table 1 summarizes each positive APP in the context of feline disease.

\section{Negative Acute Phase Proteins}

Albumin is the most relevant negative APP, with blood concentration decreasing during APR, due to amino acid deviation towards the synthesis of positive APP (CRAY et al., 2009; PALTRINIERI, 2007a).Other negative APP are transferrin, transthyretin, retinol ligand and cortisol binding protein, proteins involved in vitamin and hormone transport (JAIN et al., 2011).

\section{Acute phase proteins in feline disease}

Unlike cytokines, which have a small size and are rapidly filtered by the kidney, the acute phase proteins have a higher molecular weight (greater than $45 \mathrm{kDa}$ ), and subsequently a longer permanence in the plasma (SALGADO et al., 2011).

The APP levels can only assess inflammation and consequently their concentrations can assist in diagnosis and disease monitoring. APP can help to detect subclinical inflammation, differentiate acute from chronic disease and to predict its course (VILHENA et al, 2018; JAVARD et al., 2017). Since the APR begins before specific immunological changes occur, it can be used as an early marker for disease, before leucogram changes take place, being its magnitude related with the severity of disease (PETERSEN et al., 2004; CÉRON et al., 2005; VILHENA et al., 2018).For this reason, disease monitoring can be considered as one of the most interesting and promising applications of APP.

APP levels, together with clinical signs and blood tests have been evaluated in different animal diseases (i.e.FIP, canine inflammatory bowel disease, leishmaniasis, ehrlichiosis and canine pyometra), and proved to be useful in the diagnosis, treatment response monitoring and prognosis (ECKERSALL et al., 2001; MARTINEZSUBIELA et al., 2005; SHIMADA et al., 2002; JERGENS et al., 2003; GIORDANO et al., 2004; PETERSEN et al., 2004; DABROWSKI et al., 2009; VILHENA et al., 2018).

To obtain a complete information about APR, one major and one moderate positive, as well one negative APP should be done simultaneously (CERÓN et al., 2008). High concentrations of major APP are usually related with infectious diseases, usually a systemic bacterial infection or an immunemediated disease (CERÓN et al., 2008; TROÌA et 
Table 1 - Acute phase proteins studied in the context feline diseases.

\begin{tabular}{|c|c|c|}
\hline APP & Diseases & References \\
\hline \multirow{8}{*}{ SAA } & FIP & $\begin{array}{l}\text { DUTHIE et al., 1997; GIORDANO et al., 2004; } \\
\text { HAZUCHOVA et al. 2017; }\end{array}$ \\
\hline & Induced inflammation and surgery & KAJIKAWA et al., 1999; \\
\hline & $\begin{array}{l}\text { Various diseases (Pancreatitis, Renal failure, FLUTD, } \\
\text { Tumors, Diabetes mellitus; renal disease, injury, etc.) }\end{array}$ & $\begin{array}{l}\text { SASAKI et al., 2003; KANN et al., 2012; TAMAMOTO et al., } \\
\text { 2013; TAMAMOTO et al., 2013;JAVARD et al., 2017; }\end{array}$ \\
\hline & Sepsis & TRÒIA et al., 2017; \\
\hline & FeLV; Hemotropicmycoplasms infections & VILHENA et al., 2018; \\
\hline & Infection by Hepatozoonfelis and Babesia vogeli & VILHENA et al., 2017; \\
\hline & Dirofilariaimmitis & SILVESTRE-FERREIRAet al., 2017; \\
\hline & FIV cats treated with recombinant feline interferon & LEAL et al., 2014; \\
\hline \multirow{8}{*}{ AGP } & Infection by Chlamydophila psittaci; & TERWEE et al., 1998; \\
\hline & Pancreatitis and pancreatic tumors & MEACHEM et al., 2015; \\
\hline & Feline infectious peritonitis & $\begin{array}{l}\text { DUTHIE et al., 1997; CECILIANI, et al., 2004; GIORDANO } \\
\text { et al., 2004; BENCE et al., 2005; PALTRINIERI et al., 2007b; } \\
\text { GIORI et al., 2011; HAZUCHOVA et al., 2017; }\end{array}$ \\
\hline & Lymphoma and other tumors & $\begin{array}{l}\text { SELTING et al., 2000; CORREA et al., 2001; WINKEL et al. } \\
2015 \text {; }\end{array}$ \\
\hline & Induced inflammation and surgery & KAJIKAWA et al., 1999; \\
\hline & FIV cats treated with recombinant feline interferon & LEAL et al., 2014 \\
\hline & Abscesses, pyothorax, Fat necrosis & OTTENJANN et al., 2006; \\
\hline & $\begin{array}{l}\text { Various diseases (FLUTD, Tumors, Diabetes } \\
\text { mellitus; renal disease, injury, etc.) }\end{array}$ & KANN et al., 2012; \\
\hline \multirow{7}{*}{ Haptoglobin } & Feline infectious peritonitis & $\begin{array}{l}\text { DUTHIE et al., 1997; GIORDANO et al., 2004; } \\
\text { HAZUCHOVA, K. et al. 2017; }\end{array}$ \\
\hline & Induced inflammation and surgery & KAJIKAWA, T. et al. 1999 \\
\hline & Abscesses, Pyothorax, Fat necrosis, & OTTENJANN et al., 2006; \\
\hline & $\begin{array}{l}\text { Various diseases (FLUTD, Tumors, Diabetes } \\
\text { mellitus; renal disease, injury, etc) }\end{array}$ & KANN et al. 2012 \\
\hline & Infection by Hepatozoonfelis and Babesia vogeli & VILHENA et al., 2017; \\
\hline & FeLV, Hemotropicmycoplasms & VILHENA et al., 2018; \\
\hline & Dirofilariaimmitis & SILVESTRE-FERREIRAet al. 2017; \\
\hline \multirow[t]{2}{*}{ CRP } & FIV cats treated with recombinant feline interferon & LEAl et al., 2014 \\
\hline & Induced inflammation and surgery & KAJIKAWA et al., 1999; \\
\hline
\end{tabular}

Legend: Serum Amyloid A (SAA), $\alpha 1$-Acid Glycoprotein (AGP), Systemic Inflammatory Response Syndrome (SIRS) Feline Lower Urinary Tract Disease (FLUTD), Feline Infectious Peritonitis (FIP), Feline Leukemia Virus (FeLV), Feline Immunodeficiency Virus (FIV); Feline Calicivirus (FCV).

al., 2017). Even though APP should be analyzed together with white blood cell and neutrophil counts, they are the most sensitive in detecting inflammation and infection earliest in time (CERÓN et al., 2008; ALVES et al., 2010). However, the specificity of these proteins is low in detecting the cause of the process, being also increased in physiological states, such as pregnancy (PALTRINIERI et al., 2008).

Figure 1 illustrates the expected behavior of positive acute phase proteins based of the studies revised. The AGP, SAA and haptoglobin were pointed as useful indicators for monitoring the acute inflammatory response in cats (WINKEL et al., 2015; PALTRINIERI et al., 2007a,b; KAJIKAWA et al.,
1999). The APP in cats were firstly identified after comparative serum measurements in clinically normal and diseased animals, in experimentally induced inflammation studies, and in post-operatory studies (KAJIKAWA et al., 1999). The SAA concentration was reported to be the first to increase, with AGP and haptoglobin increasing thereafter, opposing to a less significant increase of CRP (KAJIKAWA et al., 1999). One study showed that CPR behaves similarly to SAA and AGP in feline inflammation (LEAL et al., 2014).

\section{Serum amyloid $a$}

The SAA is one of the major APP in several species, important in both Humans and 


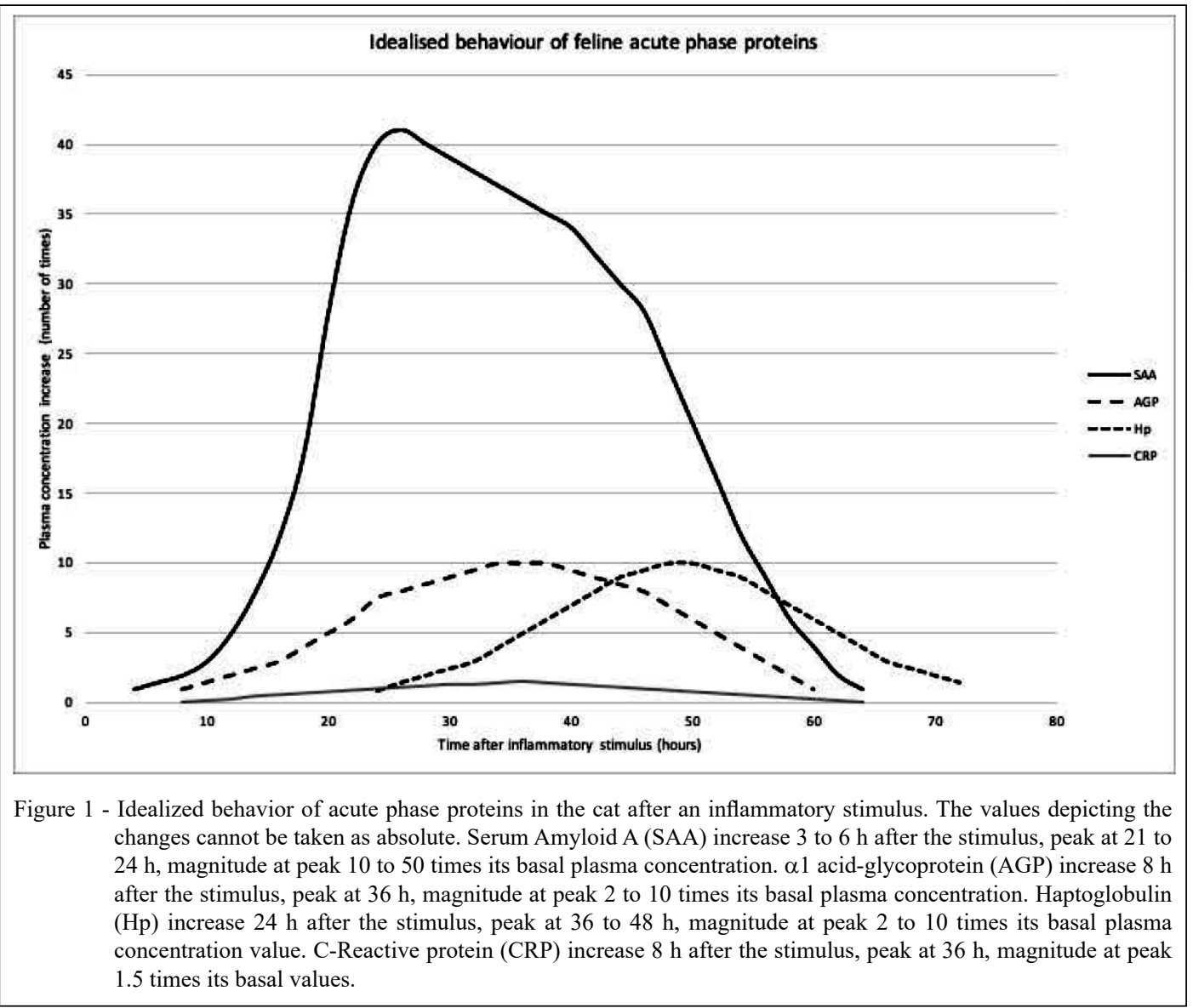

cats (KAJIKAWA et al., 1999). Modulates the immune response by attracting inflammatory cells to tissues and leading to the production of multiple inflammatory cytokines (GRUYS et al., 2005; TIZARD, 2013a). Its concentration may rise more than 1,000-fold in inflammatory status, consequently perceiving inflammation (TAMAMOTO et al., 2013). Such increase; however, is also seen in noninflammatory diseases in inflammatory diseases and in neoplasia (TAMAMOTO et al., 2013). According to a study performed in cats undergoing surgery, SAA concentration begins to increase at approximately 3 to 6 hours, achieving the highest value 21 to 24 hours postoperatively (SASAKI et al.,2003).

\section{Alpha 1-acid glycoprotein}

Alpha 1-acid glycoprotein (AGP) is an acute phase reactant protein reported in the seromucoid portion of the serum (SELTING et al., 2000; WINKEL et al., 2015). As most positive APP, AGP is a glycoprotein synthesized mostly by hepatocytes upon APR and released into the bloodstream (CÉRON et al., 2005).

AGP can be used to monitor early interferon treatment in cats infected with Feline immunodeficiency virus (FIV) (GIL et al., 2014). AGP, as well as haptoglobin ( $\mathrm{Hp})$ is increased in anemic cats suffering from pyothorax, abscesses or fat necrosis (OTTENJANN et al., 2006).

AGP changes in feline neoplasia seems to be inconsistent among studies. Some describe no changes in cats bearing lymphoma (CORREA et al., 2001). On the contrary, others show increase of both AGP or SAA in cats with sarcomas, carcinomas or other round cell tumors (SELTING et al., 2000; TAMAMOTO et al., 2013; MEACHEN et al., 2015; HAZUCHOVA et al., 2017).

The AGP has been important as an indicator test for FIP, specially used in Europe (CECILIANI et al, 2004).GIORI et al. (2011) studied the specificity and sensitivity of several tests in 12 cats, where $33.33 \%$ were FIP negative 
by histopathology and immunohistochemistry, and $66.66 \%$ of the cats were FIP positive confirmed by histopathology and immunohistochemistry. This author concluded that immunohistochemistry must always be performed to confirm FIP, but high concentrations of AGP may help to support the diagnosis of FIP in case where immunohistochemistry is not possible to perform, and histopathology is not conclusive.

\section{Haptoglobin}

Haptoglobin (Hp) is one of the most important acute-phase proteins in cattle, sheep, goat, horses and cats (TIZARD, 2013a), synthesized mostly by hepatocytes but also by other tissues, like skin, lung and kidney (JAIN et al, 2011). The Hp binds to iron molecules and makes them unavailable to invade bacteria, consequently inhibiting bacterial proliferation and invasion. Consequently it also binds to free hemoglobin, preventing its oxidation with lipids and proteins (TIZARD, 2013a), justifying the reduction of $\mathrm{Hp}$ in case of hemolysis.

In cats, Hp usually increases 2- to 10 -fold in inflammatory conditions, being especially high in FIP (TIZARD, 2013a). However, both Hp and SAA did not provide enough support to differentiate between FIP and other causes of effusion, compared with AGP (HAZUCHOVA et at., 2017).

\section{App measurement}

The serum is composed by a large number of individual proteins, in which detecting changes in its fractions can provide important diagnostic information (ECKERSALL, 2008).
Ideally, measurement of all serum proteins should be available to be used as a diagnostic tool in the context of inflammatory diseases.

Nowadays, APP (Table 2) can be determined using Enzyme-Linked Immunosorbent Assay (ELISA), radioimmunoassay, nephelometry, immunoturbidimetry (IT), Western blot, and messenger ribonucleic acid (mRNA) analysis (CÉRON et al., 2005;PALTRINIERI et al., 2008; SCHREIBER et. al, 1989). Although, some APP assays for Humans have been automated also for veterinary medicine, species-specific tests are still limited. Interspecies APP variations and the limited availability of cross-reactive reagents have contributed, for now, to a low routine determination of APP in veterinary labs, especially for cats. Regardless, technology is evolving, and it is possible to foresee in the near future routine monitoring of the clinically relevant APP in cats.

\section{CONCLUSION}

Acute phase proteins in cats are useful biomarkers to monitor inflammation, together with other clinical and laboratory findings, being useful in diagnosing subclinical changes, monitoring the evolution and the effect of a disease in the organism, as well as evaluate treatment response.

In the cat, SAA is the APP expressing the highest magnitude in response to inflammation, followed by AGP and haptoglobin, contrarily to CRP as observed in other species.

Although, there are commercially available kits for dosing feline APPs, assay standardization aiming technical simplicity, more

Table 2 - Advantages and disadvantages of possible techniques in measuring APP

\begin{tabular}{|c|c|c|c|}
\hline Analyses & Advantages & Disadvantages & References \\
\hline Radioimmunoassay & & $\begin{array}{c}24 \text { to } 48 \text { hours to get results, } \\
\text { specific skilles from the } \\
\text { operator }\end{array}$ & WHICHER et al., 1983 \\
\hline ELISA & $\begin{array}{l}\text { Commercially available } \\
\text { kits, species specific }\end{array}$ & $\begin{array}{l}\text { Lack automation, expensive, } \\
\text { some imprecision between-run }\end{array}$ & $\begin{array}{c}\text { JACOBSEN et al. } 2006 \\
\text { TECLES et al. } 2007 \\
\text { MARTÍNEZ-SUBIELA, S. et } \\
\text { al. } 2005\end{array}$ \\
\hline Immunoturbidimetry & $\begin{array}{c}30 \text { minutes to get results, } \\
\text { adaptable to biochemical } \\
\text { analyzers }\end{array}$ & & $\begin{array}{l}\text { WHICHER et al., 2003, } \\
\text { KURIBAYASHI et al., } \\
\text { 2003BENCE et al. } 2005\end{array}$ \\
\hline Western Blot & & $\begin{array}{l}\text { Long period to process } \\
\text { immunoblots }\end{array}$ & $\begin{array}{c}\text { CALLAHAN \& YATES } \\
2014\end{array}$ \\
\hline Nephelometric immunoassays & & $\begin{array}{c}\text { Depend on cross-reactivity of } \\
\text { antiserum raised }\end{array}$ & $\begin{array}{c}\text { WEIDMEYER \& SOLTER, } \\
1996\end{array}$ \\
\hline
\end{tabular}

Ciência Rural, v.49, n.4, 2019. 
species specificity with less associated costs will allow routine use in feline practice, as it done in human medicine.

\section{ACKNOWLEDGEMENTS}

The authors acknowledge the support from the Project UID/CVT/00276/2019 (CIISA) founded by FCT

\section{DECLARATION OF CONFLICT OF} INTERESTS

The authors declare no conflict of interest. The founding sponsors had no role in the collection, analyses, or interpretation of data; in the writing of the manuscript, and in the decision to publish the results.

\section{AUTHORS' CONTRIBUTIONS}

The authors contributed equally to the manuscript.

\section{REFERENCES}

ALVES, A.E. et al. Leucogram and serum acute phase protein concentrations in queens submitted to conventional or videolaparoscopic ovariectomy. Arquivo Brasileiro de Medicina Veterinaria e Zootecnia, v.62, n.1, p.86-91, 2010. Available from: $<$ http:// www.scielo.br/pdf/abmvz/v62n1/v62n1a12.pdf $>$. Accessed: Oct. 10, 2018. doi: 10.1590/S0102-09352010000100012.

BAUMANN, H. \& GAULDIE, J. The acute phase response Immunol Today, v.15, n.2, p.74-80, 1994. Available from: $<$ https://doi.org/10.1016/0167-5699(94)90137-6>. Accessed: Aug. 21, 2018. doi: 10.1016/0167-5699(94)90137-6.

BAUMANN, H. et al. Distinct regulation of the interleukin-1 and interleukin- 6 response elements of the rat haptoglobin gene in rat and human hepatoma cells. Molecular and Cellular Biology, v.10, n.11, p.5967-5976, 1990. Available from: $<$ https://mcb.asm org/content/10/11/5967> Accessed: Aug. 21, 2018. doi: 10.1128/ MCB.10.11.5967.

BENCE, L. et al. An immunoturbidimetric assay for rapid quantitative measurement of feline alpha-1-acid glycoprotein in serum and peritoneal fluid. Veterinary Clinical Pathology, v.34 n.4, p335-341, 2005. Available from: <https://doi.org/10.1111/ j.1939-165X.2005.tb00058.x>. Accessed: Jan. 13, 2019. doi: 10.1111/j.1939-165X.2005.tb00058.x.

CALLAHAN, G. \& YATES, R. Veterinary Clinical Laboratory Immunology. In Warren, A. Basic Veterinary Immunology, pp. 295-317, 2014. Boulder, Colorado: University Press of Colorado.

CECILIANI, F. et al. Decreased sialylation of the acute phase protein $\alpha 1$-acid glycoprotein in feline infectious peritonitis (FIP). Veterinary Immunology and Immunopathology, v.99, n.34, p.229-236, 2004. Available from: <https://doi.org/10.1016/j vetimm.2004.02.003 > . Accessed: Aug. 24, 2018. doi: 10.1016/j. vetimm.2004.02.003

CERÓN, J. et al. Acute phase proteins in dogs and cats: current knowledge and future perspectives. Veterinary Clinical
Pathology, v.34, n.2, p.85-99, 2005. Available from: <https:// www.ncbi.nlm.nih.gov/pubmed/15902658>. Accessed: Aug. 20, 2018. doi: 10.1111/j.1939-165X.2005.tb00019.x.

CERÓN, J.J. A seven-point plan for acute phase protein interpretation in companion animals. Veterinary Journal, v.177, n.1, p.6-7, 2008. Available from: <https://doi.org/10.1016/j. tvj1.2007.12.001>. Accessed: Aug. 20, 2018. doi: 10.1016/j. tvj1.2007.12.001.

CORREA, S.S et al. Serum alpha 1-acid glycoprotein concentration in cats with lymphoma. Journal of the American Animal Hospital Association, v.37, n.2, p.153-158, 2001. Available from: $<$ https://doi.org/10.5326/15473317-37-2-153>. Accessed: Aug. 24, 2018. doi: 10.5326/15473317-37-2-153.

CRAY, C. et al. AcutePhase Response in Animals: A Review. Comparative Medicine, v.59, n.6, p.517-526, 2009. Available from: <https://www.ncbi.nlm.nih.gov/pmc/articles/ PMC2798837/>. Accessed: Aug. 21, 2018.

DABROWSKI, R. et al. Usefulness of C-reactive protein, serum amyloid A component and haptoglobin determinations in bitches with pyometra for monitoring early postovariohysterectomy complications. Theriogenology, v.72, n.4, p.471-476, 2009. Available from: <https://doi.org/10.1016/j. theriogenology.2009.03.017>. Accessed: Aug. 23, 2018. doi: 10.1016/j.theriogenology.2009.03.017.

DUTHIE, S. et al. Value of $\alpha 1$-acid glycoprotein in the diagnosis of feline infectious peritonitis. The Veterinary Record, v.141, n.12, p.299-303, 1997. Available from: <https:/www.ncbi.nlm.nih. gov/pubmed/9330474>. Accessed: Aug. 11, 2018. doi: 10.1136/ vr.141.12.299.

ECKERSALL, P. Proteins, Proteomics, and the Dysproteinemias. In Kaneko, J., Harvey, J. \& Bruss, M. In Clinical Biochemistry of Domestic Animals. 6. ed. USA: Elsevier, 2008, Chap. 5, p.117-155.

ECKERSALL, P.D. \& BELL, R. Acute phase proteins: Biomarkers of infection and inflammation in veterinary medicine. The Veterinary Journal, v.185, n.1, p.23-27, 2010. Available from: <https:// www.ncbi.nlm.nih.gov/pubmed/20621712>. Accessed: Aug. 20, 2018. doi: 10.1016/j.tvj1.2010.04.009.

ECKERSALL, P.D. et al. Acute phase protein response in an experimental model of ovine caseous lymphadenitis. BMC Veterinary Research, v.19, p.3-35, 2007. Available from: $<$ https:// doi.org/10.1016/j.tvj1.2010.04.009>. Accessed: Aug. 24, 2018. doi: 10.1016/j.tvj1.2010.04.009.

ECKERSALL, P.D. et al. Acute phase proteins in serum and milk from dairy cows with clinical mastitis. Veterinary Record, v.148, n.2, p.35-41, 2001. Available from: <https://veterinaryrecord.bmj. com/content/148/2/35>. Accessed: Aug. 22, 2018. doi: 10.1136/ vr.148.2.35.

GIL, S. et al. Oral recombinant feline interferon-omega as an alternative immune modulation therapy in FIV positive cats: Clinical and laboratory evaluation. Research in Veterinary Science, v.96, n.1, p.79-85, 2014. Available from: <https://doi. org/10.1016/j.rvsc.2013.11.007>. Accessed: Oct. 10, 2018. doi: 10.1016/j.rvsc. 2013.11 .007

GIORDANO, A. et al. Changes in some acute phase protein and immunoglobulin concentrations in cats affected by feline infectious 
peritonitis or exposed to feline coronavirus infection. The Veterinary Journal, v.167, n.1, p.38-44, 2004. Available from: $<$ https://doi.org/10.1016/S1090-0233(03)00055-8>. Accessed: Aug. 9, 2018. doi: 10.1016/S1090-0233(03)00055-8.

GIORI, L. et al. Performances of different diagnostic tests for feline infectious peritonitis in challenging clinical cases. Journal of Small Animal Practice, v.52, n.3, p.152-157, 2011. Available from: $<$ https://doi.org/10.1111/j.1748-5827.2011.01042.x>. Accessed: Aug. 24, 2018. doi: 10.1111/j.1748-5827.2011.01042.x.

GRUYS, E. et al. Acute phase reaction and acute phase proteins. Journal of Zhejiang University. Science B, v.6, n.11, p.10451056, 2005. Available from: <http://www.jzus.zju.edu.cn/article. php?doi=10.1631/jzus.2005.B1045>. Accessed: Aug. 21, 2018. doi: 10.1631/jzus.2005.B1045

HAZUCHOVA, K. et al. Usefulness of acute phase proteins in differentiating between feline infectious peritonitis and other diseases in cats with body cavity effusions. Journal of Feline Medicine and Surgery, v.19, n.8, p.809-816, 2017. Available from: <https://doi.org/10.1177/1098612X16658925>. Accessed: Aug. 11, 2018. doi: 10.1177/1098612X16658925.

HOCHEPIED, T. et al. $\alpha 1$-Acid glycoprotein: an acute phase protein with inflammatory and immunomodulating properties. Cytokine Growth Factor Rev, v.14, n.1, p.25-34, 2003. Available from: $<$ https://doi.org/10.1016/S1359-6101(02)00054-0>. Accessed: Aug. 21, 2018. doi: 10.1016/S1359-6101(02)00054-0.

JACOBSEN, S. et al. Evaluation of a commercially available human serum amyloid A (SAA) turbidometric immunoassay for determination of equine SAA concentrations. Veterinary Journal, v.172, n.2, p.315-319, 2006. Available from: <https:// doi.org/10.1016/j.tvj1.2005.04.021>. Accessed: Aug. 24, 2018. doi: $10.1016 /$ j.tvj1.2005.04.021

JAIN, S. et al. Acute-phase proteins: As diagnostic tool. Journal of Pharmacy and Bioallied Sciences, v.3 v.1, p.118-127, 2011. Available from: <https://www.ncbi.nlm.nih.gov/pmc/articles/PMC3053509/>. Accessed: Aug. 21, 2018. doi: 10.4103/0975-7406.76489.

JAVARD R. et al. Acute phase proteins and iron status in cats with chronic kidney Disease. Journal of Veterinary Internal Medicine, v.31, n.2, p.457-464, 2017. Available from: <https:// www.ncbi.nlm.nih.gov/pmc/articles/PMC3053509/>. Accessed: Oct. 10, 2018. doi: 10.1111/jvim. 14661 .

JERGENS, A.E. et al. A scoring index for disease activity in canine inflammatory bowel disease. Journal of Veterinary Internal Medicine, v.17, n.3, p.291-297, 2003. Available from: <https:// doi.org/10.1111/j.1939-1676.2003.tb02450.x>. Accessed: Aug. 22, 2018. doi: 10.1111/j.1939-1676.2003.tb02450.x.

KAJIKAWA, T. et al. Changes in concentrations of serum amyloid A protein, alpha 1-acid glycoprotein, haptoglobin, and C-reactive protein in feline sera due to induced inflammation and surgery. Veterinary Immunology and Immunopathology, v.68, n.1, p. 91-98, 1999. Available from: <https://doi.org/10.1016/S01652427(99)00012-4> Accessed: Aug. 10, 2018. doi: 10.1016/S01652427(99)00012-4.

KANN, R. et al. Acute phase proteins in healthy and sick cats. Research in Veterinay Science, v.93, n.2. p.649-654, 2012. Available from: <https://doi.org/10.1016/j.rvsc.2011.11.007>. Accessed: Aug. 20, 2018. doi: 10.1016/j.rvsc.2011.11.007.
KURIBAYASHI, T. et al. Alpha 1-acid glycoprotein (AAG) levels in healthy and pregnant beagle dogs. Experimental Animals, v.52, n. 5, p.377-381, 2003. Available from: <https://www.jstage.jst. go.jp/article/expanim/52/5/52_5_377/_article>. Accessed: Jan. 13, 2019. doi: 10.1538/expanim.52.377

LEAL, R. et al. Monitoring acute phase proteins in retrovirus infected cats undergoing feline interferon- $\omega$ therapy. Journal of Small Animal Practice, v.55, n.1, p.39-45, 2014. Available from: $<$ https://doi.org/10.1111/jsap.12160>. Accessed: Jan. 6, 2019. doi: 10.1111 jsap. 12160

MARTÍNEZ-SUBIELA, S. et al. Validación analítica de técnicas comerciales para la determinación de haptoglobina, proteína $\mathrm{C}$ reactiva y amiloide A sérico en caninos [Analytical validation of comercial techniques for haptoglobin, $\mathrm{C}$ reactive protein and sérum amyloid A determinations in dogs]. Archivos de Medicina Veterinaria, v.37, n.1, 2005. Available from: $<$ https://scielo.conicyt. cl/scielo.php?script=sci_arttext\&pid=S0301-732X2005000100009>. Accessed: Jan. 13, 2019. doi: 10.4067/S0301-732X2005000100009.

MEACHEM, M.D. et al. A comparative proteomic study of plasma in feline pancreatitis and pancreatic carcinoma using 2-dimensional gel electrophoresis to identify diagnostic biomarkers: A pilot study. Canadian Journal of Veterinary Research, v.79, n.3, p.184-189, 2015. Available from: <https:// www.ncbi.nlm.nih.gov/pmc/articles/PMC4445510/pdf/ cjvr_07_184.pdf>.Accessed: Oct. 10, 2018.

MURATA, H. et al. Current research on acute phase proteins in veterinary diagnosis: An overview. The Veterinary Journal, v.168, n.1, p.28-40, 2004. Available from: <https://doi.org/10.1016/ S1090-0233(03)00119-9>. Accessed: Aug. 20, 2018. doi: 10.1016/ S1090-0233(03)00119-9.

OTTENJANN, M. et al. Characterization of the anemia of inflammatory disease in cats with abscesses, pyothorax, or fat necrosis. Journal of Veterinary Internal Medicine, v.2, n.5, p. 1143-1150, 2006. Available from: <https://doi. org/10.1111/j.1939-1676.2006.tb00713.x>. Accessed: Aug. 24, 2018. doi: 10.1111/j.1939-1676.2006.tb00713.x.

PALTRINIERI, S. Early biomarkers of inflammation in dogs and cats: The acute phase protein. Veterinary Research Communications, v.31, n.1, p.125-129, 2007a. Available from: $<$ https://link.springer.com/article/10.1007\%2Fs11259-007-01073\#citeas $>$. Accessed: Aug. 21, 2018. doi: 10.1007/s11259-0070107-3.

PALTRINIERI, S. et al. Serum alphal-acid glycoprotein (AGP) concentration in non-symptomatic cats with feline coronavirus (FCoV) infection. Journal of Feline Medicine and Surgery, v.9, n.4, p.271-277, 2007b. Available from: <https://doi.org/10.1016/j. jfms.2007.01.002>. Accessed: Aug. 11, 2018. doi: 10.1016/j. jfms.2007.01.002.

PALTRINIERI, S. The feline acute phase reaction. Review. The Veterinary Journal, v.111, n.1, p.26-35, 2008. Available from: $<$ https://doi.org/10.1016/j.tvj1.2007.06.005>. Accessed: Aug. 24, 2018. doi: 10.1016/j.tvj1.2007.06.005.

PETERSEN, H. et al. Application of acute phase protein measurements in veterinary clinical chemistry. Veterinary Research, v.35, n.2, p.163-187, 2004. Available from: <https:// doi.org/10.1051/vetres:2004002>. Accessed: Aug. 20, 2018. doi: 10.1051/vetres:2004002. 
SALGADO, F. J., et al. (2011). Acute phase proteins as biomarkers of disease: from Bench to Clinical Practice. In Veas, F. Acute Phase Proteins as Early Non-Specific Biomarkers of Human and Veterinary Diseases. Rijeka, Croatia: InTech. Available from: $<$ http://www.documentation.ird.fr/hor/fdi:010060045>. Accessed: Aug. 21, 2018. doi: 10.5772/1045.

SASAKI, K. et al. Evaluation of feline serum amyloid A (SAA) as an inflammatory marker. Journal of Veterinary Medical Science, v.65, n.4, p.545-8, 2003. Available from: <https://www.jstage.jst. go.jp/article/jvms/65/4/65_4_545/_pdf >.Accessed: Aug. 10, 2018.

SCHREIBER, G. et al. The acute phase response in the rodent. Annals of the New York Academy of Science, v.557, p.61-85, 1989. Available from: <https://doi.org/10.1111/j.1749-6632.1989. tb24000.x>. Accessed: Aug. 24, 2018. doi: 10.1111/j.17496632.1989.tb24000.x.

SELTING, K. et al. Serum alpha 1-acid glycoprotein concentrations in healthy and tumor-bearing cats. Journal of Veterinary Internal Medicine, v.14, n.5, p.503-506, 2000. Available from: <https:// doi.org/10.1111/j.1939-1676.2000.tb02267.x>. Accessed: Aug. 9 , 2018. doi: 10.1111/j.1939-1676.2000.tb02267.x.

SHIMADA, T. et al. Monitoring C-reactive protein in beagle dogs experimentally inoculated with Ehrlichiacanis. Veterinary Research Communications, v.26, n.3, p.171177, 2002. Available from: <https://link.springer.com/article/ 10.1023/A:1015290903332>. Accessed: Aug. 22, 2018. doi: 10.1023/A:1015290903332.

SILVESTRE-FERREIRA, A.C. et al. Serum acute phase proteins in Dirofilariaimmitis and Wolbachia seropositive cats. Journal of Feline Medicine and Surgery, v.19, n.6, p.693-696, 2017. Available from: <https://doi.org/10.1177/1098612X15625435>. Accessed: Sep. 16, 2018. doi: 10.1177/1098612X15625435.

TAMAMOTO, T. et al. Serum amyloid A as a prognostic marker in cats with various diseases. Journal of Veterinary Diagnostic Investigation, v.25, n.3, p.428-432, 2013. Available from: <https:// journals.sagepub.com/doi/pdf/10.1177/1040638713486112>. Accessed: Jan. 27, 2019.

TECLES, F. et al. Validation of a commercially available human immunoturbidimetric assay for haptoglobin determination in canine serum samples. Veterinary Research Communications, v.31, n.1, p.23-36, 2007. Available from: <https://link.springer. com/article/10.1007\%2Fs11259-006-3397-y>. Accessed: Jan. 13, 2019. doi: 10.1007/s11259-006-3397-y.

TERWEE, J. et al. Characterization of the systemic disease and ocular signs induced by experimental infection with
Chlamydia psittaci in cats. Veterinary Microbiology, v.59, 259-281, 1998. Available from: <https://doi.org/10.1016/S03781135(97)00185-5>. Accessed: Aug. 20, 2018. doi: 10.1016/ S0378-1135(97)00185-5.

TIZARD, I. Innate immunity:proinflammatory and antimicrobial mediators/systemic responses to inflammation. In Veterinary Immunology. 9.ed. St. Louis, Missouri: Saunders, Elsevier, 2013a. Chap. 6, p.52-58.

TIZARD, I. Innate immunity: proinflammatory and Atimicrobial mediators/systemic responses to Inflammation. In Veterinary Immunology. 9.ed. St. Louis, Missouri: Saunders, Elsevier, 2013b. Chap. 4, p.31-40.

TROİA, R. et al. Serum amyloid A in the diagnosis of feline sepsis. Journal of Veterinary Diagnostic Investigation, v.29, n.6, p.856-859, 2017. Available from: <https://doi. org/10.1177/1040638717722815>. Accessed: Aug. 11, 2018. doi: $10.1177 / 1040638717722815$.

VILHENA, H. et al. Acute phase proteins response in cats naturally infected by hemotropic mycoplasmas. Comparative Immunology, Microbiology \& Infectious Diseases, v.56, p.1-5, 2018. Available from: <https://doi.org/10.1016/j.cimid.2017.11.001>. Accessed: Aug. 11, 2018. doi: 10.1016/j.cimid.2017.11.001.

VILHENA, H. et al. Acute phase proteins response in cats naturally infected with Hepatozoonfelis and Babesia vogeli. Veterinary Clinical Pathology, v.48, n.1, p.72-76, 2017. Available from: $<$ https://doi.org/10.1111/vcp.12451>. Accessed: Aug. 10, 2018. doi: $10.1111 /$ vep. 12451 .

WEIDMEYER, C. \& SOLTER, P. Validation of human haptoglobin immunoturbidimetric detection of haptoglobin in equine and canine serum and plasma. Veterinary Clinical Pathology, v.24, n.4, p.141-146, 1996. Available from: <https://doi.org/10.1111/ j.1939-165X.1996.tb00988.x>. Accessed: Jan. 13, 2019. doi: 10.1111/j.1939-165X.1996.tb00988.x.

WHICHER, T. et al. Immunonephelometric and immunoturbidimetric assays for proteins. Critical Reviews in Clinical Laboratory Sciences, v.18, n.3, p.213-260, 1983. Available from: $<$ https://doi.org/10.3109/10408368209085072>. Accessed: Aug. 13, 2019. doi: 10.3109/10408368209085072.

WINKEL, V. et al. Serum $\alpha-1$ acid glycoprotein and serum amyloid A concentrations in cats receiving antineoplastic treatment for lymphoma. American Journal Veterinary Research, n.76, v.11, p.983-988, 2015. Available from: <https://doi.org/10.2460/ ajvr.76.11.983>. Accessed: Aug. 22, 2018. doi: 10.2460/ ajvr.76.11.983. 